\section{Changes in Leaf Osmotic and Elastic Properties and Canopy Structure of Strawberries under Mild Water Stress}

\author{
Robert Savé, Josep Peñuelas, Oriol Marfà, and Lydia Serrano \\ Departament de Tecnologia Hortícola, Institut de Recerca i Tecnologia \\ Agroalimentàries, Carretera de Cabrils, s/n 08348 Barcelona, Spain
}

Additional index words. canopy architecture, leaf area index, osmotic potential, specific leaf weight, turgor potential, volumetric modulus of elasticity, xylem water potential

\begin{abstract}
Field-grown strawberry (Fragaria $\times$ annanasa Duch. cv. Chandler) plants were subjected to two irrigation regimes from Nov. 1989 to July 1990 to evaluate the physiological and morphological effects of mild water stress. Irrigation was applied when soil matric potential reached -10 and-70 $\mathrm{kPa}$ for the wet and dry treatments, respectively. During the spring, these regimes did not promote significant changes in plant water relations, transpiration rates, plant morphology, or canopy architecture. However, during the summer, after several stress cycles, significant differences between treatments were observed. Pressure-volume curves of dry-treatment plants indicated that leaf osmotic potentials, measured at full and zero turgor, decreased 0.2 to $0.4 \mathrm{MPa}$. This decrease in osmotic potential also was accompanied by a $50 \%$ increase in the modulus of elasticity for these water-stressed plants compared to well-watered plants. Dry-treatment plants also showed stress avoidance mechanisms in changes of whole-plant morphology and canopy architecture, from monolayer to polylayer leaf distribution and leaf orientation from south to north. Despite what would appear to be useful drought-resistance strategies, there was significantly lower fruit production by plants grown under the dry treatment.
\end{abstract}

Horticultural crops and their wild ancestors have developed many mechanisms to survive water stress, including escape, tolerance, and avoidance of tissue water deficits. Avoidance of water stress includes changes in leaf area, anatomy, orientation, and color, among others (Jones, 1980). Tolerance to water stress usually involves two mechanisms, osmotic adjustment and changes in elastic properties of tissues (Morgan, 1984; Munns, 1988; Roberts et al., 1981; Robichaux et al., 1986; Turner, 1986).

In our part of the Mediterranean region, strawberry crops often develop moderate water stress as a consequence of either inappropriate or untimely irrigation scheduling, which often results in decreased yields (Marfà et al., 1990; Serrano et al., 1992). A better understanding of plant adaptation to drought stress may help to enhance irrigation management practices. Our objectives were to evaluate the physiological changes promoted by moderate water deficits in field-grown strawberry plants

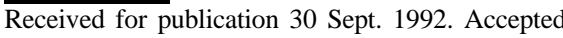
for publication 25 Mar. 1993. We thank Xavier Carbonell for invaluable help during the trial, José Montero for his assistance, and Assumpció Martinez for analytical support. A "Fundació Conde de Barcelona" grant to J.P. also is acknowledged. This research was supported partially by the program Agriculture Mediterranean-EEC and Instituto Nacional de Investigaciones Agrarias (AGRIMED INIA 60110/D) and by the Comisi6n Asesora de Investigación Cientifica y Técnica (CAYCIT, PA 86-0042, CICYT AGR90-485). The cost of publishing this paper was defrayed in part by the payment of page charges. Underpostal regulations, this paper therefore must be hereby marked advertisement solely to indicate this fact. and to assess the contribution of putative adaptation mechanisms to turgor maintenance.

'Chandler' strawberry plants were planted at our center in El Maresme, Catalonia (lat. $41^{\circ} 25^{\prime} \mathrm{N}$, long. $2^{\circ} 23^{\prime} \mathrm{E}$ ), on 10 Nov. 1989 and grown until 11 July 1990 in a Typic Xerorthent soil under a tunnel covered with thermic polyethylene plastic film. During the 2 months after planting, irrigation was applied when soil matric potentials reached $-20 \mathrm{kPa}$. Thereafter, two irrigation treatments were established in two plots of four replication beds. Each plot was $6 \times 4.5 \mathrm{~m}$, with plants set every $30 \mathrm{~cm}$ within the rows. Rows were $32 \mathrm{~cm}$ apart. Plant density was 6.4 plants $/ \mathrm{m}^{2}$.

Irrigation was applied in each plot when soil matric potential reached $-10 \mathrm{kPa}$ (wet) and $-70 \mathrm{kPa}$ (dry). Soil matric potentials were determined as the average from six tensiometers (Soilmoisture 2725; Soilmoisture, Santa Barbara, Calif.) located 10 and $20 \mathrm{~cm}$ deep and $15 \mathrm{~cm}$ apart from the emitter in each plot. Water was supplied by trickle irrigation using turbulent-flow emitters spaced $30 \mathrm{~cm}$ apart, with a flow rate of 2 liters $\cdot \mathrm{h}^{-1}$.

At each irrigation, a nutrient solution was applied. Tap water was adjusted according to Steiner's method (Steiner, 1966) to obtain the nutrient equilibria of 1:0.5:1.8 and 1:0.7:2.5 $\left(\mathrm{N}-\mathrm{P}_{2} \mathrm{O}_{5}-\mathrm{K}_{2} \mathrm{O}\right)$ for vegetative and reproductive periods, respectively. Because different irrigation regimes can alter the nutritional status of treated plants and bias results, we analyzed the $\mathrm{N}$ content of leaf and fruit samples. No significant differences were found $(P=$ $0.05)$ in fruit and leaf $\mathrm{N}$ content between the two irrigation treatments. Mean leaf $\mathrm{N}$ content was $1.98 \pm 0.14 \mathrm{SE}$ and $2.13 \pm 0.24 \mathrm{SE}$, and fruit $\mathrm{N}$ content was $1.31 \pm 0.16 \mathrm{SE}$ and $1.29 \pm 0.05$
$\mathrm{SE}$, for $-10 \mathrm{kPa}$ and $-70 \mathrm{kPa}$ treatments, respectively.

Mature leaves from the wet and dry plots were randomly selected during the mornings of 24 Apr. and 11 July 1990. They were excised, immediately sealed in plastic bags containing some water, and transported to the adjacent laboratory. Petioles were recut under water, set in beakers filled with water, and the beaker with leaf was then enclosed in a plastic bag to rehydrate for $48 \mathrm{~h}$ at $5 \mathrm{C}$ in darkness. Five water-saturated leaves were measured for each irrigation regime. They were weighed and then allowed to dehydrate by transpiration for a period during which they wererepeatedly inserted in a pressure chamber (Soilmoisture $3005)$ to determine xylem water potential $(\Psi)$ (Kikuta and Richter, 1986). Data for initial saturated weight, intermediate fresh weight corresponding to values for $\Psi$, and final dry weight were used to calculate the relative water content (RWC). The RWC and the corresponding $\Psi$, were plotted as a "Type II" $\left(\Psi{ }^{-1} X\right.$ RWC) transformation (Tyree and Richter, 1981, 1982). The parameters derived from pressure-volume $(\mathrm{P}-\mathrm{V})$ curves were osmotic potential at full $\left(\Psi_{\pi 100}\right)$ and at zero turgor $\left(\Psi_{\pi 0}\right)$, and leaf volumetric elastic modulus $(\epsilon)$ (Sobrado, 1986; Turner, 1988). At the same time, cuticular water loss rates were obtained gravimetrically on the same leaves used for P-V curve measurements (Savé, 1986; Sveningsson and Liljenberg, 1986). We considered cuticular water loss rates to be the values obtained below the point of zero turgor. Specific leaf weight (SLW) also was calculated using these same leaves.

At the end of the experiment, in July, we described canopy architecture for plants in the two irrigation regimes. Leaf area index (LAI) was calculated by measuring the central leaflet length of 12 plants from each treatment. Total area was then estimated as area $\left(\mathrm{cm}^{2}\right)=21.49 \times$ length $(\mathrm{cm})-52.62\left(\mathrm{n}=16\right.$ and $\left.r^{2}=0.9360 * * *\right)$, which was established experimentally. We classified leaves as south-, north-, and zenith-oriented. We also counted the leaves positioned every $5 \mathrm{~cm}$ from the top to the bottom of the canopy. At the same time, root biomass was determined by digging ten 35-cm-diameter and 25-cm-deep cores, each containing a plant, from each irrigation treatment. Cores were washed free of soil, and the roots were weighed. Fruit were harvested at 3day intervals, from 110 to 248 days after planting.

No significant differences were found in the parameters between irrigation treatments in the spring (Table 1). This may have been due to the low evaporative demand of the atmosphere and also to too few accumulated stress cycles. In April, 16 stress cycles had accumulated in the wet plots, while only three stress cycles had occurred in the dry plots. Average solar radiation was $17.5 \mathrm{MJ} \cdot \mathrm{m}^{-2} \cdot \mathrm{day}^{-1}$, and calculated evapotranspiration (ETP) Penmann was $100 \mathrm{~mm}$. In contrast, the daily average solar radiation in July was 23.9 $\mathrm{MJ} \cdot \mathrm{m}^{-2}$, and the calculated ETP Penmann was $151 \mathrm{~mm}$. By that time, the dry and wet plots had accumulated 16 and 39 stress cycles, re- 
Table 1. Seasonal patterns of ecophysiological parameters of strawberry plants subjected to two irrigation levels. ${ }^{2}$

\begin{tabular}{|c|c|c|c|c|}
\hline \multirow[b]{2}{*}{ Measurement ${ }^{\mathrm{v}}$} & \multicolumn{2}{|c|}{ Spring } & \multicolumn{2}{|c|}{ Summer } \\
\hline & Wet $^{x}$ & Dry & Wet & Dry \\
\hline \multicolumn{5}{|l|}{ Hydric } \\
\hline$\Psi_{\pi \mid 00}(\mathrm{MPa})$ & $-1.59 \pm 0.06^{\mathrm{Ns}}$ & $-1.70 \pm 0.09^{\mathrm{ss}}$ & $-1.43 \pm 0.05^{*}$ & $-1.85 \pm 0.08^{*}$ \\
\hline$\Psi_{\pi 0}(\mathrm{MPa})$ & $-1.98 \pm 0.05^{\text {s }}$ & $-1.99 \pm 0.09^{\mathrm{Ns}}$ & $-1.89 \pm 0.03^{*}$ & $-2.10 \pm 0.04^{*}$ \\
\hline$\in(\mathrm{MPa})$ & $6.17 \pm 0.20^{\mathrm{ss}}$ & $6.96 \pm 0.18^{\mathrm{Ns}}$ & $5.46 \pm 0.66^{\prime}$ & $8.18 \pm 0.36^{*}$ \\
\hline $\mathrm{TR}_{\mathrm{c}}\left(\mu \mathrm{g} \cdot \mathrm{cm}^{-2} \cdot \mathrm{s}^{-1}\right)$ & $1.13 \pm 0.06^{\mathrm{Ns}}$ & $1.06 \pm 0.07^{\mathrm{Ns}}$ & $1.04 \pm 0.28^{\mathrm{Ns}}$ & $1.23 \pm 0.10^{\mathrm{ws}}$ \\
\hline \multicolumn{5}{|l|}{$\begin{array}{l}\text { Morphological } \\
\text { and productivity }\end{array}$} \\
\hline SLW $\left(\mathrm{mg} \cdot \mathrm{cm}^{-2}\right)$ & $6.37 \pm 0.11^{\text {Ns }}$ & $6.35 \pm 0.09^{\mathrm{Ns}}$ & $5.86 \pm 0.19^{*}$ & $7.83 \pm 0.08^{*}$ \\
\hline LAI & $2.61 \pm 0.12^{\mathrm{Ns}}$ & $1.98 \pm 0.10^{\text {Ns }}$ & $5.10 \pm 0.27^{*}$ & $2.55 \pm 0.14^{*}$ \\
\hline $\begin{array}{l}\text { Accumulated fruit } \\
\text { production }\left(\mathrm{kg} \cdot \mathrm{m}^{-2}\right)\end{array}$ & $1.84 \pm 0.16^{*}$ & $1.41 \pm 0.14^{*}$ & $7.81 \pm 0.43^{*}$ & $4.98 \pm 0.49^{*}$ \\
\hline
\end{tabular}

${ }^{2}$ Wet is $-10 \mathrm{kPa}$ and dry is $-70 \mathrm{kPa}$ of soil matric potential.

${ }^{y} \Psi_{\pi 100}$ and $\Psi_{\pi 0}$ are osmotic potentials at full and zero turgor, respectively, and $\in$ is the volumetric modulus of elasticity. $\mathrm{TR}_{\mathrm{c}}$ is cuticular transpiration rate, $\mathrm{SLW}$ is specific leaf weight, and LAI is leaf area index. ${ }^{\circledR}$ Each value is the mean of five observations \pm SE.

Ns, "Nonsignificant or significant, respectively, between treatments at $P \leq 0.05$ by analysis of variance.

spectively. In July, there were significant differences in osmotic potential at full and zero turgor, volumetric elastic modulus, SLW, LAI, leaf distribution, and orientation or fruit yield between treatments (Table 1). The $\Psi_{\pi 100}$ and $\Psi_{\pi 0}$ were $29 \%$ and $11 \%$ lower, respectively, in the dry treatment, suggesting some degree of osmotic adjustment in response to water deficits (Morgan, 1984; Turner, 1986; Turner and Jones, 1980). This decrease in the dry treatment can be caused partially by the concentration of solutes (Ackerson and Hebert, 1981; Sobrado, 1986) due to a small reduction in cell size as shown by the increase in SLW. The high values of $\epsilon$ in the dry treatment ( $\epsilon$ was $50 \%$ higher in stressed than in well-watered plants, and it was $16 \%$ higher in summer than in spring) indicate lower tissue elasticity. This decrease in tissue elasticity causes an increase in the magnitude of the change in turgor pressure for a given fractional change in tissue water content (Myers and Neales, 1986; Robichaux et al., 1986). There were no significant differences in cuticular transpiration rates $\left(\mathrm{TR}_{\mathrm{c}}\right)$ between irrigation treatments (Table 1).

There were also changes in LAI, leaf angle, and leaf anatomy. Dry-treatment plants had a $50 \%$ lower LAI than wet-treatment plants (Table 1). This change in LAI provides an important alternative for water loss regulation (Jones, 1980). We also found differences in canopy architecture between irrigation regimes. Plants from the dry treatment tended to form a polylayer canopy, with leaves distributed along a vertical profile, while plants from the wet treatment tended to form a monolayer canopy, as shown by the vertical profile of leaf distribution (Table 2). North and south leaf orientation was also clearly distinct in the irrigation treatments (Table 2). Most leaves of plants in the wet treatment were south-oriented, while most leaves of plants in the dry treatment were north-oriented. Both modifications in canopy architecture suggest a strategy to increase light absorption efficiency while controlling water loss (Fisher, 1986; Givnish, 1986; Morris, 1989; Nobel, 1983).

Root biomass was similar for the irrigation regimes. In July, the root biomass was $4.60 \pm$ 0.91 for wet and $4.23 \pm 0.83 \mathrm{~g}$ dry weight/plant for dry treatments. The lack of differences may be explained by the irrigation system employed in which only a fraction of the available soil volume was wetted (Renquist et al., 1982).

From our results, we can conclude that strawberry plants in the wet treatment were subjected to very mild water stress and showed a tolerance mechanism based on high elasticity of tissues, thus permitting a greater use of nutrients and assimilates for growth (Munns, 1988), while turgor-mediated processes, such as elongate growth and photosynthesis, could be maintained (Bradford and Hsiao, 1982). Strawberry plants in the dry plots maintained leaf turgor pressure by tolerance and avoidance mechanisms (Levitt, 1980; Morgan, 1984). These plants tolerated drought by actively accumulating solutes that allowed osmotic adjustment. Together with less elastic tissues, this mechanism allows leaves to reach more negative water potentials for a given change in water volume, facilitating continued water uptake from drying soil (Bowman and Roberts, 1985). Moreover, dry-treatment plants developed mechanisms of drought avoidance. They had higher SLW, their LAI was lower, and leaves were mostly oriented to

Table 2. Distribution and orientation of strawberry leaves at the end of the production period in the summer for plants subjected to two irrigation regimes.

\begin{tabular}{lrr}
\hline \hline Characteristic & Wet $^{\mathrm{x}}$ & Dry \\
\hline $\begin{array}{l}\text { Vertical distribution } \\
\text { (cm above soil) }\end{array}$ & Leaf canopy $(\%)$ & \\
$>25$ to 30 & $37 \pm 6^{y}$ & $7 \pm 4$ \\
$>20$ to 25 & $26 \pm 5$ & $23 \pm 8$ \\
$>15$ to 20 & $13 \pm 4$ & $23 \pm 5$ \\
$>10$ to 15 & $15 \pm 2$ & $25 \pm 5$ \\
$>5$ to 10 & $8 \pm 1$ & $15 \pm 2$ \\
0 to 5 & $1 \pm 0.6$ & $7 \pm 2$ \\
Orientation & $17 \pm 2$ & $41 \pm 6$ \\
$\quad$ North & $31 \pm 2$ & $38 \pm 8$ \\
Zenith & $52 \pm 4$ & $21 \pm 2$ \\
South &
\end{tabular}

${ }^{2}$ Wet is $-10 \mathrm{kPa}$ and dry is $-70 \mathrm{kPa}$ of soil matric potential.

${ }^{\mathrm{y}}$ Each value is the mean of 10 observations $\pm \mathrm{SE}$. the north. They also were distributed randomly in height instead of mainly in the upper part of the canopy as in the wet treatment (Givnish, 1986; Jones, 1980). In spite of these adaptations, final fruit production in the dry treatment was lower than in the wet treatment (Table 2).

Thus, 'Chandler' plants developed several physiological adaptations to water stress, such as osmotic adjustment, similar to that described by Archbold and Zang (1991) in Fragaria virginiana Duch. and $F$. chiloensis (L.) Duch. However, in contrast with the results obtained by those authors, we also found morphological adaptations that seemed to play an important role in the adaptation of this strawberry cultivar to drought stress.

\section{Literature Cited}

Ackerson, R.C. and R. Hebert. 1981. Osmoregulation in cotton in response to water stress. I. Alterations in photosynthesis, leaf conductance, translocation and ultrastructure. Plant Physiol. 67:484-488.

Archbold, D.D. and B. Zhang. 1991. Drought stress resistance in Fragaria species, p. 138-144. In: A. Dole and J.L. Luby (eds.). The strawberry into the 21st century. Timber Press, Portland, Ore.

Bowman, W.D. and S.W. Roberts. 1985. Seasonal changes in tissue elasticity in chaparral shrubs. Physiol. Plant. 65:233-236.

Bradford, K.J. and T.C. Hsiao. 1982. Physiological response to moderate water stress, p. 263-324. In: O.L. Lange, P.S. Nobel, C.B. Osmond, and H. Ziegler (eds.). Physiological plant ecology II. vol. 12B. Springer-Verlag, Berlin.

Fisher, J.B. 1986. Branching patterns and angles in trees, p. 493-524. In: T.J. Givnish (ed.). On the economy of plant form and function. Cambridge Univ. Press, Cambridge, U.K.

Givnish,T.J. 1986. Bioehemical constraints on crown geometry in forest herbs, p. 525-584. In: T.J. Givnish (ed.). On the economy of plant form and function. Cambridge Univ. Press, Cambridge, U.K.

Jones, H.G. 1980. Interactions and integration of adaptive responses to water stress: The implications of an unpredictable environment, p. 353366. In: N.C. Turner and P.J. Kramer (eds.). Adaptations of plants to water and high temperature stress. Wiley, New York.

Kikuta, S.B. and H. Richter. 1986. Graphical evaluation and partitioning of turgor responses to drought in leaves of durum wheat. Planta 168:3842.

Levitt, J. 1980. Water stress, p. 25-211. In: T.T. Kozlowski (ed.). Responses of plants to environmental stresses. II. Water, radiation, salt and other stresses. Physiol. Ecol. Ser. Academic, New York.

Marfà, O., F. Reguant, L. Serrano, M. Joaniquet, and A. Tardà. 1990. El sector maduixaire a l'Alt Maresme: Bases tècniques per a la millora de la productivitat. FIRESME, Mataró, p. 300.

Morgan, J.M. 1984. Osmoregulation and water stress in higher plants. Annu. Rev. Plant Physiol. 35:299-319.

Morns, J.T. 1989. Modelling light distribution within the canopy of the marsh grass Spartina alterniflora as a function of canopy biomass and solar angle. Agr. For. Meteorol. 46:349-361.

Munns,R. 1988. Why measure osmotic adjustment? Austral. J. Plant Physiol. 15:717-726.

Myers, B.A. and T.F. Neales. 1986. Osmotic adjust- 
ment induced by drought in seedlings of Eucalyptus species. Austral. J. Plant Physiol. 13:597603 .

Nobel, P.S. 1983. Biophysical plant physiology and ecology. Freeman, New York.

Renquist, A.R., P.J. Breen, and L. W. Martin. 1982. Vegetative growth response of 'Olympus' strawberry to polyethylene mulch and drip irrigation regimes. J. Amer. Soc. Hort. Sci. 107:369-372.

Roberts, S.W., B.R .Strain, and K.R. Knoerr. 1981. Seasonal variation of leaf tissue elasticity in four forest tree species. Physiol. Plant. 52:245-250.

Robichaux, R.H., K.E. Holsinger, and S.R. Morse. 1986. Turgor maintenance in Hawaiian Dubautia species: The role of variation in tissue osmotic and elastic properties, p. 353-380. In: T.T. Givnish (ed.). On the economy of plant form and function. Cambridge Univ. Press, Cambridge, U.K.

Savé, R. 1986. Ecofisiologia de les relacions hídriques de l'alzina en el Montseny. PhD Diss., Univ. Aut6noma de Barcelona.

Serrano, L., X. Carbonell, R. Savé, O. Marfà and J. Peñuelas. 1992. Effects of irrigation regimes on the yield and water use of strawberry. Irr. Sci. 13:45-48.

Sobrado, M.A. 1986. Aspects of tissue water relations and seasonal changes of leaf water potential components of evergreen and deciduous species coexisting in tropical dry forest. Oecologia 68:413-416.

Steiner, A.A. 1966. The influence of the chemical composition of a nutrient solution on the production of tomato plants. Plant Soil 24:454466.

Svenningsson, M. and C .Liljenberg. 1986 .Changes in cuticular transpiration rate and cuticular lipids of oat (Avena sativa) seedlings induced by water stress. Physiol. Plant. 66:9-14.

Turner, N.C. 1986. Adaptation to water deficits: A changing perspective. Austral. J. Plant Physiol. 13:175-190.

Turner, N.C. 1988. Measurement of plant water status by pressure chamber technique. Irr. Sci. 9:289-308

Turner, N.C. and M.M. Jones. 1980. Turgor maintenance by osmotic adjustment: A review and evaluation, p. 87-104. In: N.C. Turner and P.J. Kramer (eds.). Adaptation of plants to water and high temperature stress. Wiley, New York.

Tyree, M.T. and H. Richter. 1981. Alternative methods of analysing water potential isotherms: Some cautions and clarifications. I. The impact of non-ideality and some experimental errors. J. Expt. Bot. 32(128):643-653.

Tyree, M.T. and H. Richter. 1982. Alternative methods of analysing waterpotential isotherms: Some cautions and clarifications. II. Curvilinearity in water potential isotherms. Can. J. Bot. 60:911916. 